\title{
NMYC Gene Amplification
}

National Cancer Institute

\section{Source}

National Cancer Institute. NMYC Gene Amplification. NCI Thesaurus. Code C36673.

A molecular genetic abnormality indicating the presence of multiple copies of the MYCN gene. 